\title{
PERAN NAZHIR DALAM MENGELOLA HASIL WAKAF UANG PADA BADAN WAKAF INDONESIA JAWA TIMUR'
}

\author{
Risca Putri Prasinanda \\ Departemen Ekonomi Syariah-Fakultas Ekonomi dan Bisnis-Universitas Airlangga \\ Email: riscaaa44@gmail.com \\ Tika Widiastuti \\ Departemen Ekonomi Syariah-Fakultas Ekonomi dan Bisnis-Universitas Airlangga \\ Email:widasus@yahoo.com
}

\begin{abstract}
ABTRACT:
This research aims at determining the competence of Nazhir on its efforts to manage cash waqf to empower productive society. Analysis technic done on this study is descriptive qualitative with case study method where this research is done by doing direct observation, taking documentation and all the data provided, and interviewing all the related parties to this matter, so that the data gained are able to answer all the research questions. The result of this research show that Indonesian Waqf Board has done its duty in accordance with the Regulation no 41 year 2004 to manage and develop cash waqf properly, it needs human resources which are reliable, professional, knowledgeable in economics, perseverance, and having strong commitment. Therefore, cash waqf institution has a really strategic role on creating a productive waqf in Indonesia, therefore a training is needed to the waqf managers (nazhirs), a continuous socialization from academicians, ulamas, sharia economics practicians, either from seminar, training, preaches, or mass media articles.
\end{abstract}

Keywords: Baitul Mal Wat Tamwil, Financing Fund, Prosperity, SME, Maqasid shariah.

\section{PENDAHULUAN}

Problematika sosial dan kesejahteraan ekonomi Indonesia akhirakhir ini dilanda dengan berbagai macam permasalahan. Kesenjangan sosial, pengangguran dan kemiskinan berjalan beriringan semakin bertambah. Indonesia sebagai Negara berkembang pada saat ini struktur ekonominya telah mengalami ketimpangan. Ketimpangan tersebut dikarenakan basis perekonomiannya telah di monopoli oleh sebagian kalangan feodalis-tradisional, yaitu kelompok yang menguasai basis ekonomi di kawasan pedesaan sejak zaman penjajahan hingga saat ini.

Dewasa ini, wakaf adalah salah satu potensi besar yang mampu memperbaiki keadaan suatu Negara. Keberadaan wakaf memang sangat strategis sebagai salah satu sumber peningkatan kualitas perekonomian negara. Allah SWT dalam QS. Ali-Imron 3:92 berfirman:

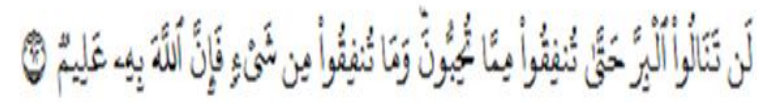

Lan tanahul-birra hatta tunfiqu mimma tuhibbun, wa ma tunfiqu min syai'in fa innallaha nihi 'alim.

"Kamu sekali-kali tidak sampai kepada kebajikan (yang sempurna), sebelum kamu menafkahkan sehahagian harta yang kamu cintai. Dan apa saja yang kamu nafkahkan maka sesungguhnya

\footnotetext{
1 Jurnal ini merupakan bagian dari skripsi dari Risca Putri Prasinanda, NIM: 041211431021, yang diuji pada 16 Juli 2019.
} 
Allah mengetahuinya."

Shihab (2009:177) menjelaskan ayat diatas bahwa kapan dan bagaimana sehingga nafkah seseorang akan dapat bermanfaat yakni bahwa yang dinafkahkan hendaknya harta yang disukai dengan cara yang baik dan tujuan serta motivasi yang benar.

Wakaf vang merupakan implementasi produk baru dalam sejarah perekonomian islam yang dipelopori oleh Muhammad Abdul Mannan, di Bangladesh. Menurut Abdul Mannan, wakaf vang dapat berperan sebagai suplemen bagi pendanaan berbagai macam proyek investasi social yang dikelola oleh bank-bank islam, sehingga dapat berubah menjadi bank wakaf. Dana wakaf yang terkumpul selanjutnya diinvestasikan oleh nazhir kedalam berbagai sector usaha yang halal dan produktif. Keberadaan nazhir memegang peranan penting terhadap perkembangan harta wakaf, dimana pendayagunaan wakaf vangbergaris lurus dengan kemampuan nazhir (Rahmat Dahlan, 2009).

Menurut Nasution \& Hasanah (2005:43-44) jika ada lembaga wakaf yang mampu mengelola wakaf uang secara professional, maka lembaga ini merupakan sarana baru bagi umat islam untuk beramal.

Berdasar data BPS 2014 jumlah penduduk Indonesia 252 juta jiwa,penduduk Muslim $80 \%$ atau sekitar adalah 201 juta. Badan Wakaf Indonesia
(BWI) mencatat, aset wakaf vang yang sudah terkumpul di Indonesia per Desember 2013 baru mencapai Rp 145,8 miliar. Sedangkan potensi wakaf uang sebesar Rp 120 triliun per tahunnya. Potensi ini diasumsikan 100 juta warga negara bersedia mewakafkan uangnya sebesar Rp 100 ribu/ bulan. Aset wakaf vang tertinggi di Indonesia saat ini per Desember 2013 masih dipegang oleh Dompet Dhuafa sekitar Rp 83.155 juta, kemudian pada posisi kedua ada Lembaga Bangun Nurani Bangsa ESQ sekitar Rp 47 juta, PKPU sekitar Rp 4.559 juta, setelah itu baru BWI sekitar Rp 4.093 juta.

Sebagai salah satu instrumen kevangan dalam islam, wakaf tidak dapat terpisahkan dari sistem ekonomi dengan tujuan kemaslahatan umat melalui pemberdayaan masyarakat. Kompetensi seorang nazhir yang professional merupakan hal penting yang harus dipertimbangkan dalam pengelolaan dana wakaf, dimana seorang nazhir harus mampu mengelola dana wakaf agar memiliki nilai tambah sebagai modal untuk mengembangkan aset wakaf secara produktif.

Potensi wakaf di Indonesia yang begitu besar sangat memungkinkan untuk dikelola secara produktif. Pengelolaan wakaf saat ini bisa dilakukan oleh pihak perorangan, organisasi, dan berbadan hokum. Salah satu pengelola wakaf ada Badan Wakaf Indonesia (BWI). Badan Wakaf Indonesia (BWI) berdiri pada 
tanggal 10 februari 2010. Menurut $\mathrm{KH}$ Tholhah Hasan peresmian kantor pewakilan Jawa Timur dimaksudkan untuk memaksimalkan potensi wakaf di daerah tersebut.

\section{LANDASAN TEORI}

\section{Konsep Wakaf}

Secara etimologi, kata wakaf berasal dari kata waqafa-yaqifu-waqfan, yang mempunyai arti berdiri tegak, menahan. Istilah fikih yang semakna dengan wakaf antara lain, al-habs dan as-sabiil, maka tidak heran di dalam kitab Imam Syafi'l dan al-Kutub as-Sittah menyebut wakaf dengan menggunakan lafaz al-habs. Dari segi_okum_ology, para ulama memiliki beragam pemahaman sehingga menimbulkan perbedaan dalam aplikasi wakaf. Jadi, jika berbicara masalah wakaf berarti dari aset atau harta seseorang atau kaum muslimin yang diperuntukkan untuk kemaslahatan umat diambil benefit atau keuntungannya dan pokoknya yang ditahan (Hadi, 2009:15).

Halim (2005:7), wakaf ialah menyerahkan hak milik yang zatnya dapat bertahan lama kepada seseorang atau nazhir (orang yang mengurus wakaf) atau kepada badan pengelola dengan ketentuan yaitu hasil dan manfaatnya digunakan sesuai ketentuan Islam dan benda yang telah diwakafkan nantinya bukan lagi menjadi milik wakif (orang yang mewakafkan) maupun tempat yang menyerahkan, melainkan menjadi milik Allah SWT.

Menurut Kompilasi Hukum Islam
(KHI) wakaf adalah perbuatan hukum seseorang atau kelompok orang atau badan hukum yang memisahkan sebagian dari benda miliknya dan melembagakannya untuk selamalamanya guna kepentingan ibadah atau keperluan umum lainnya sesuai dengan ajaran islam, sedangkan menurut UU No. 41 Tahun 2004 tentang wakaf.

\section{Hukum Wakaf}

Wakaf dalam islam dijelaskan secara eksplisit atau tidak disebutkan secara langsung. Kata "wakaf" dalam AlQur'an memang tidak disebutkan secara tegas. Namun maknanya mengandung pengertian mengenai wakaf dan juga perbuatan wakaf merupakan telaah dari Rasulullah SAW dan para sahabat. Allah berfirman dalam Al-Qur'an sebagai berikut :

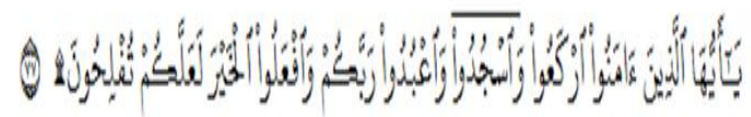

yaa ayyuha alladziina aamanuu irka'vu wausjjuduu wau'buduu rabbakum waif'aluu alkhayra la'allakum tuflihuuna "Hai orang-orang yang beriman, ruku'lah kamu, sujudlah kamu, sembahlah Tuhanmu dan perbuatlah kebajikan, supaya kamu mendapat kemenangan". (QS. Al-haij 22:77)

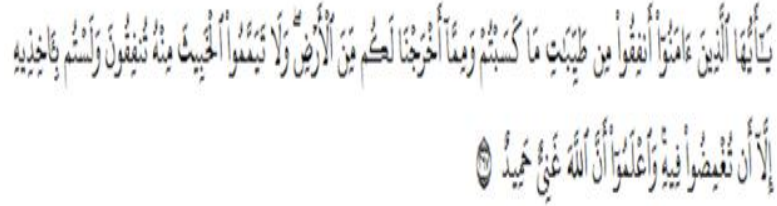

yaa ayyuhaaa alladzina aamanuu anfiquu min thayyibaati maa kasabtum 
wamimmaa akhrajnaa lakum mina alardhi walaa tayammamuvalkhabiitsa minhu tunfiquuna walastum bi-aakhidziihi illaa an tughmidhuu fiihi wai'lamuvanna allaaha ghaniyyun hamiidun

"Hai orang-orang yang beriman, nafkahkanlah (di jalan Allah) sebagian dari hasil usahamu yang baik-baik dan sebagian dari apa yang Kami keluarkan dari bumi untuk kamu. Dan janganlah kamu memilih yang buruk-buruk lalu kamu menafkahkan daripadanya, padahal kamu sendiri tidak mau mengambilnya melainkan dengan memincingkan mata terhadapnya. Dan ketahuilah, bahwa Allah Maha Kaya lagi Maha Terpuji." (QS. Al-Baqarah 2:267)

Kedua ayat diatas menjelaskan tentang perintah Allah SWT kepada umatNYA untuk menegakkan sholat dan berbuat kebaikan. Kebaikan yang dimaksud adalah melaksanakan wakaf. Ketika seseorang melaksanakan wakaf maka apa yang diwakafkan akan memberikan manfaat untuk umat, maka inilah letak kemenangannya, orang yang berwakaf akan terus mendapatkan pahala yang mengalir.

\section{Macam-macam Wakaf}

Menurut Dirjen Bimas Islam (2007:14), wakaf dapat dibedakan menjadi dua macam, antara lain:

1. Wakaf Ahli/ wakaf dzurri

Wakaf dzurri yaitu ditujukan untuk orang-orang tertentu baik yang merupakan dari keluarga wakif atau bukan. Wakaf ini juga dapat disebut sebagai wakaf 'alal aulad yang beraqrit wakaf yang diperuntukkan di lingkungan keluarga maupun kepentingan-kepentingan tertentu sebagai jaminan sosial. Namun manfaatnya dianggap kurang dikarenakan memberikan ketidakpastian dalam hal pengelolaannya.

2. Wakaf Khairi

Wakaf khairri yaitu wakaf yang digunakan untuk kepentingan agama dan kemaslahatan umat. Wakaf jenis ini dianggap dapat memberikan banyak manfaat daripada wakaf lainnya. Hal ini dikarenakan wakaf khairri dirasa memiliki lebih banyak manfaatnya.

Dalam pasal 16 ayat 1 telah disebutkan bahwa harta benda wakaf terdiri dari:

a. Benda bergerak

b. Benda tidak bergerak

\section{Rukun dan Syarat Wakaf}

Menurut Wahbah Az-Zuahili (2011:275), rukun adalah bagian sesuatu yang mana sesuatu itu tidak bisa terwujud kecuali dengan bagian itu. Karena ia merupakan "elemen (unsur) dasar bagi wujud wakaf" (Anwar Ibrahim, 2002:6). Maka dapat dipahami bahwa rukun wakaf adalah hal yang paling mendasar yang wajib terpenuhi demi terwujudnya wakaf.

Dalam perspektif Figh Islam dan perspektif Kompilasi Hukum Islam, wakaf harus memenuhi empat rukun (unsur) (Rachmadi Usman, 2009:59 dan 66) 
1. Wakif, yaitu orang yang berwakaf

2. Mauquf Bih, yaitu benda yang diwakafkan

3. Nadzir, yaitu pihak yang diserahi wakaf

4. Aqad atau Lafaz atau Sighat, yaitu pernyataan penyerahan wakaf dari pihak wakif kepada orang atau tempat berwakaf (mauquf 'alaih)

\section{Manfaat Wakaf}

Tujuan wakaf adalah memberikan sebagian atau seluruh harta benda kepada golongan tertentu atau ahli yang sudah ditunjuk yang digunakan untuk kepentingan umum atau untuk masyarakat secara luas. Berikut ini adalah manfaat wakaf yang dilihat secara umum:

1. Menimbulkan jiwa sosial yang tinggi. Wakaf seperti manfaat sedekah yang bisa menjadi salah satu sarana untuk melatih jiwa sosial sehingga yang memiliki harta benda lebih banyak bisa memberikan kepada kaum yang tidak mampu.

2. Membuat seseorang menjadi lebih sadar bahwa semua harta benda yang dimiliki bersifat tidak kekal. Manfaat agama dalam kehidupan manusia ini berhubungan dengan harta yang kita miliki juga harus dibagi dengan orang lain atau ada sebagian hak orang lain dalam harta kita.

3. Wakaf mempererat tali persaudaraan. Hubungan masyarakat antara orang yang kaya dan miskin biasanya akan mengalami kesenjangan karena perbedaan derajat yang masih dipandang oleh masyarakat. Ketika orang yang kaya memberikan wakaf untuk digunakan secara umum maka orang yang kekurangan juga bisa merasakan sarana secara umum. Tindakan ini dapat membuat hubungan masyarakat yang lebih harmonis.

4. Membantu orang lain yang mendapat kesulitan. Manfaat wakaf yang diberikan kepada seseorang yang memiliki kesulitan, misalnya berupa tanah yang diberikan untuk orang yang kesulitan dan keadaan yang payah sehingga tidak memiliki tempat tinggal.

5. Amalan wakaf tidak terputus meskipun sudah meninggal dunia menjadi salah satu sarana amalan yang bisa membuat manusia selamat di dunia dan akherat.

\section{Pemberdayaan Ekonomi Melalui Wakaf}

Salah satu lembaga ekonomi islam yang sangat berperan dalam pemberdayaan ekonomi umat adalah wakaf. Dalam sejarah, wakaf telah memerankan peran penting dalam pengembangan sosial, ekonomi, dan budaya masyarakat. Hal-hal yang paling menonjol dari lembaga wakaf adalah peranannya dalam membiayai berbagai pendidikan Islam dan kesehatan. Kesinambungan manfaat hasil wakaf dimungkinkan oleh berlakunya wakaf produktif yang didirikan untuk menopang berbagai kegiatan sosial dan keagamaan

\section{Konsep Wakaf Produktif}


Salah satu bentuk wakaf produktif adalah wakaf uang dan wakaf pada umumnya yakni tanah atau perkebunan. Wakaf uang telah dikenal dalam dunia Islam sudah sejak dnasti mamluk. Secara ilmu fiqih wakaf dalam bentuk uang ada sebagian ulama memperbolehkan ada yang melarangnya. Allah telah berfirman:

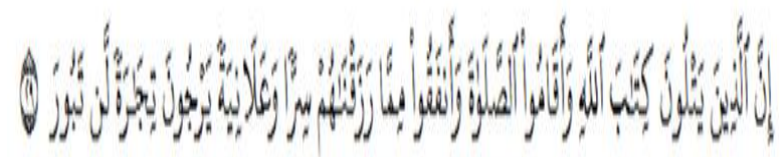

"Sesungguhnya orang-orang yang selalu membaca kitab Allah dan mendirikan shalat dan menafkahkan sebagian dari rezeki yang Kami anugerahkan kepada mereka dengan diam-diam dan terangterangan, mereka itu mengharapkan perniagaan yang tidak akan merugi." (QS. Faathir 35:29)

Ayat diatas memiliki makna bahwa apabila kita hendak mewakafkan harta yang kita miliki, maka rezeki kita justru tidak akan berkurang bahkan akan bertambah. Sehingga apabila kita melakukan wakaf secara produktif, maka sama halnya kita berinvestasi agar keuntungan kita akan semakin besar untuk mempergunakannya demi kemaslahatan umat manusia.

Pengelolaan dana wakaf vang sebagai alat untuk investasi menjadi menarik, karena tujuan utama diinvestasikannya dana wakaf adalah untuk mengoptimalkan fungsi harta wakaf sebagai prasarana untuk meningkatkan kualitas hidup dan kehidupan sumber daya insani. Hal inilah yang diharapkan mampu meningkatkan keharmonisan antara masyarakat kaya dan masyarakat miskin.

\section{Pengertian Wakaf Uang}

Wakaf vang (cash waqf/waqf alnuqud) adalah wakaf yang dilakukan seseorang, kelompok orang, lembaga, atau badan hokum dalam bentuk uang. Dengan kata lain, wakaf uang merupakan perbuatan hukum wakif untuk memisahkan dan/atau menyerahkan sebagian harta benda miliknya yang berupa uang untuk dimanfaatkan selamanya atau untuk jangka waktu tertentu, sesuai dengan kepentingannya guna keperluan ibadah dan/atau kesejahteraan umum menurut syariat. Pada dasarnya, yang dimaksud wakaf vang adalah dalam keadaan apapun vang wakaf tidak boleh berubah, baik itu berubah menjadi bangunan ataupun tanah. Namun, dana wakaf uang tersebut dapat diinvestasikan dalam bentuk usaha. Artinya, nazhir tidak boleh memanfaatkan uang wakaf tersebut secara langsung, akan tetapi yang dimanfaatkan adalah hasil dari pengelolaan wakaf uang.

\section{Sejarah Wakaf Uang}

Dalam sejarah, wakaf uang telah dipraktikkan sejak awal abad kedua Hijriah. Hal tersebut dilakukan berdasarkan pendapat beberapa ulama, diantaranya adalah pendapat Imam al-Zuhri (wafat $124 \mathrm{H}$ ) yang telah memfatwakan bahwa mewakafkan dinar hukumnya boleh, dengan cara menjadikan dinar tersebut sebagai modal usaha kemudian 
keuntungannya disalurkan pada mauquf "alaih (Abu Su'ud:1997). Selain al-Zuhri, generasi awal ulama mazha Hanafi juga telah membolehkan wakaf vang dinar dan dirham sebagai pengecualian atas dasar Istihsan bi al-"Urfi, berdasarkan atsar Abdullah bin Mas'ud ra: Apa yang dipandang baik oleh kaum muslimin maka dalam pandangan Allah adalah baik, dana apa yang dipandang buruk oleh kaum muslimin maka dalam pandangan Allah pun buruk. Dan, sebagian ulama mazhab al-Syafi'l juga ada yang memfatwakan tentang kebolehan wakaf dinar dan dirham/uang (al-Mawardi:1994).

Wakaf uang (cash waqf) pertama kali dipakai pada masa Ustman di Mesir, diakhir abad ke-16 (1555-1823 M).Pada era Ustman di Mesir, berkembang pemakaian fikih Hanafi dalam menjalankan aktivitas bisnis dan sosialnya. Imam Muhammad asy-Syaibani menjelaskan bahwa sekalipun tidak ada dukungan hadits yang kuat, penggunaan harta bergerak sebagai wakaf dibolehkan, jika memang hal itu sudah menjadi kebiasaan umum pada daerah tertentu. Bahkan bagi Imam Muhammad al-Sarakhsi, kebiasaan umum tidak selalu menjadi persyaratan dalam penggunaan harta bergerak sebagai harta wakaf. Terdapat tiga alasan mendasar kenapa ahli figh era Ustmani menyusun bangunan wakaf vang: pertama, pandangan bahwa aset bergerak dapat menjadi harta wakaf, kedua, penilaian dan penerimaan atas vang sebagai aset bergerak. Ketiga, persetujuan atas pemberian vang. Kepopuleran wakaf vang terjadi setelah Profesor Mannan mensosialisasikannya di Bangladesh melalui Social Invesment Bank Limited (SIBL). SIBL membuat Sertifikat wakaf uang (Cash Waqf Certificate) utuk mengumpulkan dana dari orang kaya dan membagi perolehan wakaf uang yang telah dikumpulkannya kepada orang-orang miskin. Popularitas "wakaf vang", ditimbulkan fleksibilitas penyebaran manfaat wakaf vang kepada kalangan mustadh'afin (orang fakir dan orang yang tertindas ekonominya) dan dhu'afa' (orang miskin) di segala tempat.

\section{Konsep Wakaf Uang}

Wakaf dengan menggunakan vang tunai membuka peluang yang unik bagi penciptaan investasi di bidang keagamaan, pendidikan, serta kegiatan sosial. Masyarakat yang berpenghasilan tinggi dapat dimanfaatkan melalui penukaran sertifikat wakaf tunai. Sedangkan pendapatan yang diperoleh dari pengelolaan wakaf tunai tersebut dapat digunakan untuk berbagai kepentingan kemaslahatan umat.

Dari pengertian tersebut dapat dirumuskan bahwa wakaf tunai merupakan dana yang dihimpun oleh pengelola wakaf (nadzir) melalui penerbitan sertifikat wakaf tunai yang dibeli oleh masyarakat. Wakaf tunai juga dapat diartikan mewakafkan harta berupa vang atau surat berharga yang 
dikelola oleh institusi (perbankan atau lembaga keuangan syariah) yang keuntungannya akan disedekahkan, dengan syarat modalnya tidak bisa dikurangi untuk sedekahnya, sedangkan dana wakaf yang terkumpul selanjutnya dapat digulirkan dan diinvestasikan oleh nadzir ke dalam berbagai sector usaha yang halal dan produktif, sehingga keuntungannya dapat dimanfaatkan untuk pembangunan umat dan bangsa secara keseluruhan.

\section{Tujuan dan Manfaat Wakaf Uang}

Adapun tujuan dibentuknya wakaf vang ini, sebagaimana disebutkan Syafi' Antonio adalah sebagai berikut:

1. Wakaf uang jumlahnya bisa bervariasi, sehingga seseorang yang memiliki dana terbatas pun bisa memberikan dana wakafnya tanpa harus menunggu menjadi tuan tanah (hartawan) terlebih dahulu.

2. Melalui wakaf uang, aset-aset wakaf yang berupa tanah-tanah kosong bisa mulai dimanfaatkan dengan pembangunan gedung atau diolah untuk lahan pertanian.

3. Wakaf uang juga bisa digunakan untuk membantu sebagian lembagalembaga islam yang kembang kempis dan menggaji civitas akademika ala kadarnya.

Sama dengan tujuan wakaf sebagaimana umumnya, wakaf uang dibuat untuk tujuan kesejahteraan kelvarga dan kesejahteraan sosial. Caranya, setiap donator dipersilahkan memilih skim yang diinginkan, kemudian menyalurkan donasinya kepada lembaga yang menjadi pengelola wakaf uang tersebut. Dengan dasar itulah nantinya lembaga wakaf uang akan mengelola donasi tersebut.

\section{Potensi Wakaf Uang di Indonesia}

Dalam penerapan wakaf tunai di Indonesia, pemerintah sendiri membentuk sebuah badan khusus yang mengelola dana wakaf yakni Badan Wakaf Indonesia (BWI) yang mempunyai fungsi sangat strategis. Harapannya badan tersebut dapat membantu, baik dalam pembinaan maupun pengawasan terhadap nadzir untuk dapat melakukan pengelolaan wakaf secara produktif. Pembentukan BWI bertujuan untuk menyelenggarakan administrasi pengelolaan secara nasional dan promosi program yang akan diadakan oleh BWI dalam rangka sosialisasi kepada umat Islam dan umat lainnya. Pola organisasi kelembagaan BWI harus merespon terhadap persoalan-persoalan yang dihadapi masyarakat pada umumnya dan umat Islam khususnya.

Menurut perhitungan Nasution tentang potensi wakaf di Indonesia dengan jumlah umat muslim dermawan diperkirakan sebesar 10 juta jiwa dengan rata-rata penghasilan perbulan Rp. 500.000 hingga Rp. 10.000.000, maka paling tidak akan terkumpul dana per bulan sekitar tiga puluh triliun rupiah per tahun dari dana wakaf. Berdasarkan contoh perhitungan tersebut maka terlihat 
bahwa keberhasilan lembaga untuk memobilisasi dana wakaf akan sangat menentukan manfaat keberadaan lembaga wakaf. Yang jadi masalahnya, vang tersebut tidak dapat langsung diberikan kepada mauquf 'alaih, tetapi nadzir harus mengelola dan mengembangkannya terlebih dahulu.

\section{Pengertian Nazhir Wakaf}

Nazhir adalah pihak yang menerima harta benda wakaf dari wakif untuk dikelola dan dikembangkan sesuai dengan peruntukannya. Posisi Nazhir sebagai pihak yang bertugas untuk memelihara dan mengurusi harta wakaf mempunyai kedudukan yang penting dalam perwakafan. Sedemikian pentingnya kedudukan Nazhir dalam perwakafan, sehingga berfungsi tidaknya wakaf bagi mauquf alaih sangat bergantung pada nazhir wakaf. Meskipun demikian tidak berarti bahwa nazhir mempunyai kekuasaan mujtlak terhadap harta yang di amanahkan kepadanya.

\section{Standarisasi Nazhir Professional}

Ciri atau karakteristik professional sebagaimana dirumuskan oleh Departemen Agama RI Direktorat Pengembangan Zakat dan Wakaf Direktorat Jenderal Bimbingan Masyarakat Islam dan Penyelenggaraan Haji (2005, p.75-78) dan Rozalinda (2015, p.53) yakni:

1. Mempunyai keahlian dan keterampilan khusus untuk dapat menjalankan pekerjaan dengan baik. Keahlian dan keterampilan ini biasanya dimiliki dari pendidikan, pelatihan dan pengalaman yang diperoleh dalam jangka waktu tertentu. Pengetahuan, keahlian dan keterampilan ini memungkinkan seseorang professional menjalankan tugasnya dengan tingkat keberhasilan dengan mutu yang baik.

2. Adanya komitmen moral tinggi. Untuk profesi pelayanan sosial, komitmen moral dituangkan dalam bentuk kode etik profesi. Etika ini merupakan peraturan yang harus dijalankan dalam melaksanakan pekerjaan.

3. Orang yang professional, biasanya hidup dari profesi yang digelutinya.

4. Legalisasi, keizinan untuk profesi yang menyangkut kepentingan orang banyak yang terkait dengan nilai-nilai kemanusiaan, maka profesi tersebut haruslah profesi yang sah dan diizinkan.

5. Pengabdian kepada masyarakat, adanya komitmen moral yang tertuang dalam kode etik profesi dimana orangorang yang mengemban suatu profesi lebih mengutamakan kepentingan masyarakat daripada kepentingan dirinya.

\section{Macam-macam Nazhir}

Berdasarkan UU Nomor 41 Tahun 2004 tentang wakaf, Nazhir dibagai menjadi 3 kategori, yaitu:

1. Perseorangan

2. Organisasi

3. Badan Hukum

\section{Pengertian Pemberdayaan Ekonomi Masyarakat}

Menurut Ginandjar Kartasasmita (1996), pemberdayaan ekonomi 
masyarakat adalah upaya yang merupakan pengerahan sumber daya untuk mengembangkan potensi ekonomi rakyat untuk meningkatkan produktivitas rakyat sehingga baik sumber daya manusia maupun sumber daya alam di sekitar keberadaan rakyat dapat ditingkatkan produktivitasnya.

\section{Kemiskinan}

Pandangan Islam tentang kemiskinan, disebabkan oleh beberapa faktor, diantaranya karena keterbatasan untuk berusaha, penindasan, cobaan Tuhan. Namun, di negara kita sesungguhnya faktor-faktor di atas sudah mulai dibenahi, walaupun ada yang secara sungguh-sungguh maupun setengah-setengah. Mulai dari program pemerintah dan masyarakat sendiri samasama berjuang memerangi kemiskinan.

Masalah kemiskinan yang terjadi saat ini tidak bisa dilepaskan dari meningkatnya jumlah pengangguran. Pada masa krisis ekonomi ini, bukan saja laju pertambahan angkatan kerja baru tidak bisa diserap oleh pasar tenaga kerja di tanah air melainkan juga terjadi pemutusan hubungan kerja di sektor formal yang berakibat bertambahnya angkatan kerja yang menganggur penuh atau sama sekali tidak bekerja (open unemployment) maupun yang setengah menganggur atau bekerja di bawah jam kerja normal (under employment).

\section{METODE PENELITIAN}

\section{Pendekatan Penelitian}

Metode penelitian pada umumnya terdapat dau jenis yaitu pendekatan kuantitatif dan pendekatan kualitatif. Berdasarkan rumusan masalah, penelitian ini menggunakan pendekatan penelitian kualitatif. Dimana data yang terkumpul akan diolah dan dianalisis secara terperinci. Metode kualitatif adalah metode penelitian yang digunakan untuk meneliti kondisi obyek misalnya perilaku, presepsi, motivasi tindakan dan lainnya.

Dari beberapa strategi pendekatan, metode yang digunakan dalam penelitian ini adalah studi kasus. Secara umum, studi kasus merupakan strategi strategi yang cocok bila pokok pertanyaan suatu penelitian berkenaan dengan how atau why. Bila peneliti hanya memiliki sedikit peluang untuk mengontrol peristiwa-peristiwa yang akan diselidiki, dan bilamana fokus penelitiannya terletak pada fenomena kontemporer (masa kini) di dalam konteks kehidupan nyata (Yin, 2009:1).

\section{Ruang Lingkup Penelitian}

Penelitian yang dimaksud adalah untuk menjawab rumusan masalah "Bagaimana kemampuan seorang nazhir mengelola wakaf uang dalam mendayagunakan dana wakaf sehingga dapat optimal untuk mendorong perekonomian masyarakat secara produktif?". Rumusan masalah tersebu† yang akan menjadi acuan bagi peneliti untuk menentukan ruang lingkup penelitian. Penelitian ini dilakukan di Badan Wakaf Indonesia Sidoarjo Jawa 
Timur.

\section{Jenis dan Sumber Data}

Data dalam penelitian kualitatif dibagai menjadi dua jenis yaitu data primer (utama) dan data sekunder (penunjang). Dalam penelitian kualitatif, pengumpulan data bukan hanya melalui partisipasi juga melalui literature, baik sebagai data primer maupun sebagai data sekunder. Data primer diperoleh dengan wawancara langsung yaitu menanyakan sesuatu kepada seorang informan. Sedangkan data sekunder dapat diperoleh melalui penelitian sebelumnya yang berupa arsip, laporanlaporan masa lalu, dan dokumendokumen yang relevan serta kajian pustaka yang berkaitan dengan permasalahan.

\section{Prosedur Pengumpulan Data}

1. Persiapan awal

Saat persiapan awal, peneliti mengurus surat izin penelitian skripsi secara formal paada bagian akademik Fakultas Ekonomi dan Bisnis (FEB) Universitas Airlangga untuk izin wawancara ke pihak-pihak terkait di Badan Wakaf Indonesia. Tujuan mendatangi lembaga wakaf ini adalah untuk mendapatkan informasi mengenai proses pengumpulan data hingga pendistribusiannya kepada para mauquf alaih secara jelas dan terperinci.

2. Proses memasuki obyek penelitian Peneliti segera menemui ketua Badan Wakaf Indonesia setelah melakukan konfirmasi, juga membawa surat izin penelitian secara formal dari FEB UNAIR sebagai pelengkap.

3. Saat di lokasi atau obyek penelitian

Peneliti menjelaskan maksud dan tujuan penelitian kepada ketua Badan Wakaf Indonesia, kemudian melakukan observasi secara langsung pada datadata lembaga wakaf, bagaimana penggunaan dana wakaf yang diperoleh. Peneliti juga melakukan wawancara yang mendalam pada pihak-pihak terkait lainnya. Hal ini dilakukan beberapa hari secara terusmenerus secara berkala sampai peneliti mendapatkan jawaban dari rumusan masalah yang telah dibuat sebelumnya.

4. Pengumpulan data

Peneliti mengumpulkan data primer yang diperoleh dari observasi dan wawancara dengan pimpinan, coordinator, dan warga setempat secara terbuka dan berkala. Materi wawancara akan berkembang pada pertemuan berikutnya tetapi tetap terfokus dan mengarah pada topik penelitian sehingga mendapat informasi yang semakin lengkap dan akurat. Untuk data sekunder, pengumpulan datanya berdasarkan pada kajian pustaka dan literatur mengenai nilai fathonah dalam pengelolaan bisnis, yang diperoleh dengan membaca buku di ruang baca FEB atau mengakses e-book di internet. 


\section{Teknik Keabsahan Data}

Teknik yang digunakan untuk pengujian keabsahan data adalah triangulasi sumber. Teknik triangulasi sebagai teknik untuk mengecek keabsahan data, dimana dalam pengertiannya triangulasi adalah teknik pemeriksaan keabsahan data yang memanfaatkan sesuatu yang lain dalam dalam membandingkan hasil wawancara terhadap obyek penelitian. Triangulasi yang digunakan dalam penelitian ini adalah triangulasi sumber untuk mengecek data yang diperoleh dari informan mengenai pengaruh seorang nazhir dalam upaya mengelola wakaf vang untuk pemberdayaan perekonomian masyarakat yang produktif yang dilihat dari Badan Wakaf Indonesia. Triangulasi dapat dilakukan dengan menggunakan teknik yang berbeda yaitu wawancara, observasi dan dokumen.

\section{HASIL DAN PEMBAHASAN}

\section{Gambaran Umum Objek Penelitian}

Profil Badan Wakaf Indonesia

Kelahiran Badan Wakaf Indonesia (BWI) merupakan perwujudan amanat yang digariskan dalam Undang-Undang Nomor 41 Tahun 2004 tentang wakaf. Kehadiran BWI, sebagaimana dijelaskan dalam pasal 47 adalah untuk memajukan dan mengembangkan perwakafan di Indonesia. Untuk kali pertama, keanggotaan BWI diangkat oleh Presiden Indonesia, sesuai dengan Keputusan Presiden (Kepres) No. 75/M tahun 2007, yang ditetapkan di Jakarta, 13 Juli 2007.
Jadi, BWI adalah lembaga independen untuk mengembangkan perwakafan di Indonesia yang dalam melaksanakan tugasnya bersifat bebas dari pengaruh kekuasaan manapun, serta bertanggung jawab kepada masyarakat.

Berdirinya Badan Wakaf Indonesia berawal dari banyaknya tanah wakaf dan inovasi pengembangan wakaf yang belum terdata dan terkelola dengan baik, sehingga pendataan dan pembimbingan atas Nazhir perlu diadakan sosialisasi dan pembinaan. Berdirinya BWI menjadi starting point untuk membangkitkan gerakan wakaf. Yang secara filosofis wakaf sebagai salah satu lembaga islam telah menjadi salah satu penunjang perkembangan masyarakat islam dari peradaban zaman keemasan islam hingga saat ini.

\section{Visi, Misi dan Tujuan BWI}

Visi dan Misi Badan Wakaf Indonesia adalah dalam rangka mewujudkan lembaga Independen yang dipercaya masyarakat, mempunyai kemampuan dan integritas untuk mengembangkan perwakafan nasional dan internasional. Sedangkan misi menjadikan Badan Wakaf Indonesia sebagai lembaga professional yang mampu mewujudkan potensi dan manfaat ekonomi harta benda wakaf untuk kepentingan ibadah dan pemberdayaan masyarakat.

$\begin{array}{lrr}\begin{array}{l}\text { Wakaf Uang } \\ \text { Keunggulan }\end{array} & \text { wakaf } & \text { vang } \\ \text { dibandingkan } & \text { dengan } & \text { wakaf }\end{array}$


konvensional antara lain sebagai berikut (Suhrawardi, 2010; 113):

1. Wakaf uang lebih produktif, kelebihan wakaf vang yang lain adalah lebih produktif, dananya langsung dapat dimanfaatkan, hasil investasi dana wakaf langsung dapat dipergunakan untuk berbagai keperluan kemaslahatan umat, seperti beasiswa, membiayai perawatan orang sakit, membayar gaji guru, dan lain-lain.

2. Keunggulan lainnya, wakaf uang dapat dipergunakan untuk mendanai dan mengembangkan harta wakaf berupa tanah dan bangunan untuk kepentingan usaha produktif. Seperti membangun pertokoan, kedai, swalayan, rumah sakit, dan sebagainya.

3. Lebih mudah dilaksanakan oleh waqif, karena wakaf uang dapat diamalkan oleh siapa saja tanpa menunggu kaya terlebih dahulu. Dengan kata lain dapat diamalkan sesuai dengan kemampuan ekonomi sekarang. Selain itu dapat diamalkan secara berjamaah atau berkelompok, seperti wakaf Geser (gerakan seribu rupiah), setelah nominal wakaf sampai Rp 100.000 baru dikeluarkan sertifikat wakaf tunai atas nama jamaah atau kelompok.

\section{Gambaran Umum Wakaf Uang di Indonesia}

Di Indonesia, wakaf uang mulai dikembangkan pada tahun 2001 ke atas. Pakar ekonomi Islam melihat banyaknya aset wakaf di Indonesia yang tidak diberdayakan dengan produktif, yaitu 73.88\% aset wakaf hanya menjadi bangunan sarana ibadah seperti masjid dan mushola (Kemenag 2016). Pada tahun 2002, MUI mengeluarkan fatwa yang membolehkan wakaf uang. UU No. 41 Tahun 2004 tentang Wakaf juga mengatur wakaf uang dengan melibatkan Lembaga Keuangan Syariah sebagai Penerima Wakaf Uang (LKS-PWU). Wakaf uang bisa menjadi solusi untuk memberdayakan aset wakaf nasional yang idle atau menganggur dan tidak termanfaatkan selama ini.

Badan Wakaf Indonesia (BWI) sebagai lembaga independen yang membawahi nazhir wakaf nasional berdiri sejak tahun 2007 berdasarkan Kepres No. 75/M/2007 Tanggal 13 Juli 2007 tentang Kepengurusan Badan Wakaf Indonesia. Tercatat hingga tanggal 31 Desember 2015, terdapat 102 lembaga nazhir wakaf vang yang telah resmi terdaftar di BWI. Namun mayoritas dari nazhir wakaf uang tersebut hanya sedikit saja yang mengelola wakaf uang sesuai dengan regulasi dan hukum yang telah ada.

\section{Peran Nazhir Dalam Pengelolaan Wakaf Produktif}

Inti yang terkandung dalam ajaran wakaf menghendaki agar harta wakaf tidak dibiarkan tanpa ada hasil. Ini karena, semakin banyak hasil harta wakaf yang dapat dinikmati orang, akan semakin besar pula pahala yang mengalir kepada Wakif. Berdasarkan hal tersebut, pengembangan harta wakaf secara 
produktif merupakan kewajiban yang harus dilakukan oleh orang atau sekelompok orang yang dalam istilah fikih wakaf disebut Nazhir.

Nazhir adalah orang atau sekelompok orang yang bertanggung jawab untuk mengurusi, mengelola, menjaga dan mengembangkan harta wakaf. Nazhir dapat dilakukan oleh orang yang berwakaf (Wakif) sendiri atau orang lain yang ditunjuk oleh Wakif, atau mauquf "alaih (orang atau pihak yang menerima manfaat atau hasil wakaf), atau pemerintah apabila si Wakif tidak menunjuknya. Apabila wakif menunjuk nazhir kepada beberapa orang secara berurutan, seperti: saya tunjuk si A menjadi nazhir wakaf saya, dan kalau dia meninggal supaya diganti si $B$, dan kalau dia meninggal supaya diganti si C. Maka, penunjuk wakif tersebut harus dipenuhi (Hasan, 2011: 3).

\section{v. SIMPULAN}

Dengan dimasukannya vang dalam perundang-undangan Republik Indonesia melalui Undang-Undang No. 41 tahun 2004, merupakan angin segar dan peluang baru bagi umat Islam Indonesia untuk mengelola dan mengembangkan suatu potensi dana umat yang cukup besar dengan produktif dan professional dalam meningkatkan kesejahteraan ekonomi kaum muslimin dan melepaskan umat Islam dari kemiskinan. Bahkan dimungkinkan, wakaf uang bisa menjadi jalan alternatif untuk melepas ketergantungan bangsa ini dari lembaga- lembaga kreditor multilateral sekaligus menstimulasi pertumbuhan ekonomi Indonesia khususnya ekonomi Islam. Sebagai negara yang berpenduduk mayoritas Islam, eksistensi instrumen syariah ini memiliki prospek yang baik dan cerah serta akan sangat diterima oleh masyarakat Indonesia sehingga wakaf vang diperkirakan akan memberikan konstribusi besar bagi percepatan pembangunan di Indonesia.

\section{Saran}

Adapun saran dari peneliti untuk Badan Wakaf Indonesia, sebagai berikut:

1. Sebagai lembaga independen yang mengurusi perwakafan di Indonesia, diharapkan lebih gencar lagi dalam mensosialisasi dan mengedukasi masyarakat tentang perwakafan, khususnya wakaf uang, baik melalui media cetak, media elektronik, maupun melalui Humas Badan Wakaf Indonesia, sehingga para calon wakif lebih memahami apa itu wakaf uang dan lebih mengenal Badan Wakaf Indonesia.

2. Dengan jaringan yang dimiliki Badan Wakaf Indonesia diharapkan dengan instansi-instansi lain, media massa, dapat lebih meningkatkan lagi jumlah pemasukan wakaf uang, bekerja sama dengan lembaga lain dalam mensosialisasi wakaf uang.

3. Peneliti berharap agar Badan Wakaf Indonesia menetapkan target wakaf vang yang harus diperoleh, agar jumlah wakaf uang yang masuk pun 
lebih banyak lagi. Sehingga penyaluran hasil dari wakaf uang lebih merata lagi.

\section{DAFTAR PUSTAKA}

Agustianto, Wakaf Uang dan Peningkatan Kesejahteraan Umat (Artikel Zona Ekonomi Islam), di publikasikan pada Agustus, 2010.

Departemen Agama Rl, 2004 \& 2007, Pamplet Pemberdayaan Tanah Wakaf Secara Produktif (Upaya Pengembangan Potensi Ekonomi Umat), Jakarta: Dirjen Bimas Islam Direktorat Pemberdayaan wakaf

Departemen Agama. 2008. Strategi Pengembangan Wakaf Tunai di Indonesia. Jakarta. Direktorat Wakaf

https://bwi.or.id/index.php/pengertianwakaf-tentang-wakaf-54.html http://iethafairuz.blogspot.co.id/2014/11h adis-wakaf.html

http://www.kompasiana.com

Patton, Michael Quinn. 1987. Triangulasi dalam Moleong (Ed). Metode Penelitian Kualitatif Edisi Revisi (Hal 327). Cetakan ke-29. Bandung: PT. Remaja Rosdakarya

Peraturan Badan Wakaf Indonesia Nomor 2 Tahun 2009, Pasal 3, Jakarta, 2009 586

Undang-Undang Republik Indonesia Nomor 41 Tahun 2004 Tentang Waqaf

Undang-Undang Republik Indonesia Nomor 41 Tahun 2004, (Jakarta: Dirjen Bimas Islam dan Penyelenggaraan haji, 2005)

Yin, Robert K. 1998 \& 2009. Studi Kasus: Desain dan Metode, Terjemahan. Jakarta: PT Grafindo Persada. 